\title{
Vertical distribution of exopolymer particles in sea ice of the Fram Strait (Arctic) during autumn
}

\author{
Klaus Meiners ${ }^{1,5, *}$, Rolf Gradinger ${ }^{2}$, Johanna Fehling ${ }^{1,3}$, Giuseppe Civitarese ${ }^{4}$, \\ Michael Spindler ${ }^{1}$
}

\author{
${ }^{1}$ Institute for Polar Ecology, University of Kiel, Wischhofstraße 1-3, Gebäude 12, 24148 Kiel, Germany \\ ${ }^{2}$ Institute of Marine Science, University of Alaska, Fairbanks, Alaska 99775, USA \\ ${ }^{3}$ Dunstaffnage Marine Laboratory, Scottish Association for Marine Science, Oban PA34 4AB, Scotland, UK \\ ${ }^{4}$ Consiglio Nazionale delle Ricerche (CNR), Istituto di Scienze Marine, 34123 Trieste, Italy
}

${ }^{5}$ Present address: Yale University, Dept. of Geology and Geophysics, PO Box 208109, New Haven, Connecticut 06520-8109, USA

\begin{abstract}
The concentration and size distribution of exopolymer particles were measured in and below pack ice in the Fram Strait area during autumn 1999. Vertical profiles of exopolymer particles were determined in young, first-year and multi-year sea ice. In addition, a variety of abiotic parameters (temperature, salinity, $\mathrm{NO}_{2}, \mathrm{PO}_{4}, \mathrm{NO}_{3}, \mathrm{SiO}_{2}$ ) and biotic parameters (particulate organic carbon [POC] and nitrogen [PON], chlorophyll $a$ [chl a], abundances of diatoms and bacteria) were measured. Median abundances and areas of exopolymer particles in the different ice types $\left(3.17 \times 10^{6}\right.$ to $4.90 \times 10^{6}$ particles $\mathrm{l}^{-1}$ and $4.6-6.9 \mathrm{~cm}^{2} \mathrm{l}^{-1}$, respectively) exceeded median concentrations in the under-ice water $\left(0.56 \times 10^{6}\right.$ particles $\left.\mathrm{l}^{-1} ; 0.6 \mathrm{~cm}^{2} \mathrm{l}^{-1}\right)$ by 1 order of magnitude. Exopolymer particle concentrations in sea ice were highest in the interior of the sea ice and were significantly correlated with $\mathrm{chl} a$ as well as with the abundances of pennate diatoms, centric diatoms and bacteria. Our data indicate that pennate diatoms are the main producers of exopolymer particles in sea ice. The observed exopolymer particle-size spectra in both sea ice and under-ice water differed from those commonly reported for exopolymer particles in pelagic environments by a relatively large fraction of large particles. Crude estimates of integrated exopolymer particle carbon indicate that these particles can be important components in the context of food-web structure and organic carbon dynamics in the sea ice habitat. The high concentrations of exopolymer particles in the sea ice will also impact the fate of other particles during ice melt.
\end{abstract}

KEY WORDS: Sea ice $\cdot$ Nutrients $\cdot$ Exopolymer particles $\cdot$ Extracellular polymeric substances $\cdot$ EPS . Diatoms $\cdot$ Bacteria

Resale or republication not permitted without written consent of the publisher

\section{INTRODUCTION}

Sea ice is a prominent feature of Arctic marine ecosystems, with a minimum and maximum extent of $7 \times 10^{6} \mathrm{~km}^{2}$ and $14 \times 10^{6} \mathrm{~km}^{2}$, respectively (Maykut 1985). During ice formation, planktonic and detrital material is harvested from the pelagial and incorporated into the sea ice by various physical processes (Shen \& Ackermann 1990, Spindler 1994). After a short period of adaptation to the new environment some organisms start growing and develop so-called 'sympagic' communities, comprising various groups of organisms such as viruses, bacteria, protists and metazoans (Horner et al. 1992). The actual habitat of the organisms is a partially interconnected network of brine-filled channels comprising 1 to $30 \%$ of the ice volume (Weeks \& Ackley 1986, Krembs et al. 2001). The brine volume is a function of ice temperature and ice bulk salinity (Frankenstein \& Garner 1967, Weeks \& Ackley 1986). The sympagic organisms are adapted to the environmental conditions in the brine channels and can use the brine-channel walls as sites for attachment, locomotion and grazing (Gradinger \& Ikävalko 1998, Krembs et al. 2000). When the ice melts, the sea 


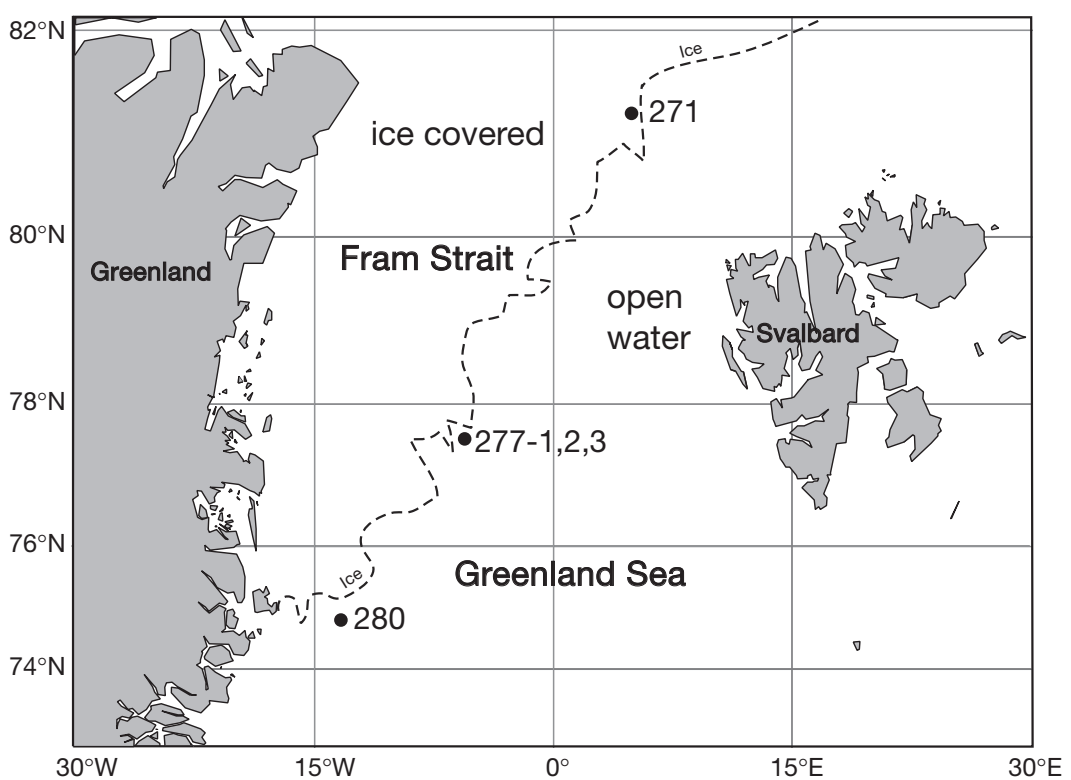

Fig. 1. Location of stations in Fram Strait area. Station numbers represent day of the year. Dashed line indicates ice edge on 20 September 1999 (day of the year $=263$ )

ice derived material is released to the water column (Gradinger et al. 1999), where former sea ice algae either continue growth in the surface layer or sink to greater depths (Carey 1987, Smith \& Sakshaug 1990, Riebesell et al. 1991, Fortier et al. 2002).

There is currently substantial interest in the role of extracellular polymeric substances (EPS) in aquatic environments. In benthic habitats especially, pennate diatoms have been shown to produce copious amounts of EPS which serve the organisms in various functions, e.g. in adhesion, locomotion, biogenic habitat stabilisation as well as in protection against harsh environmental conditions (e.g. Hoagland et al. 1993, Cooksey \& Wigglesworth-Cooksey 1995, Smith \& Underwood 1998, Wetherbee et al. 1998). In the plankton, high concentrations of EPS in the particulate phase, consisting mainly of polysaccharides, have been observed during and subsequent to diatom blooms (Alldredge et al. 1993, Passow et al. 1994, Leppard 1995). Planktonic exopolymer particles can be formed biotically by bacteria and algae in the form of capsules and sheets, but are mainly formed abiotically by coagulation of dissolved organic matter and colloidal precursors (Zhou et al. 1998, Stoderegger \& Herndl 1999, Passow 2000, 2002). Various studies have shown that exopolymer particles are important in the aggregation of diatom blooms, provide the matrix of marine snow and have a large influence on the particle flux in the ocean (Passow \& Alldredge 1994, Mari \& Kiørboe 1996, Engel \& Schartau 1999, Passow et al. 2001).
Many of the dominant ice algae produce extensive extracellular mucilages, and large quantities of EPS have been suggested to occur within the sea ice habitat (McConville 1985, Riebesell et al. 1991, Gradinger \& Nürnberg 1996, Herborg et al. 2001). To our knowledge, however, quantification of EPS in natural sea ice has only been performed in one study: Krembs \& Engel (2001) investigated the lowermost $10 \mathrm{~cm}$ of Arctic first-year pack ice and reported high exopolymer particle concentrations at the ice-water interface. However, they provided no information on the vertical distribution of exopolymer particles within the sea ice. Since Arctic pack ice can harbour productive and biomass-rich bacterial and algal communities in its interior also (Gradinger \& Zhang 1997, Gradinger 1999, Mock \& Gradinger 1999), information on EPS over the entire ice thickness is needed to understand the importance of exopolymeric substances to the sea ice habitat and the ice-covered ocean.

In this study we report on exopolymer particles in sea ice of varying age: young, first-year and multi-year sea ice. Exopolymer particles were quantified and characterised over the entire ice thickness and compared to values observed in the under-ice water. We hypothesise that the more extreme living conditions in the upper parts of the sea ice enhance exopolymer particle production, making exopolymer particles a potentially important (and until now largely neglected) source of organic carbon for the nutrition of sympagic animals and bacteria.

\section{MATERIALS AND METHODS}

The material for this study was sampled during Expedition 'ARK XV-3' with the RV 'Polarstern' to the Fram Strait and Greenland Sea in September and October 1999 (for details see Schauer 2000). A total of 5 sets of ice samples were obtained with a motorpowered CRREL-type ice corer (internal diameter $9 \mathrm{~cm}$ ) from 3 locations (Fig. 1). For each sample set, 2 ice cores (A and B) were sampled within an area of $1 \mathrm{~m}^{2}$.

Core A was used for the determination of ice temperature, bulk salinity, inorganic nutrient concentrations $\left(\mathrm{NO}_{2}, \mathrm{PO}_{4}, \mathrm{NO}_{3}, \mathrm{SiO}_{2}\right)$ and particulate organic carbon (POC) and nitrogen (PON). Ice temperatures were measured with a Testo720 thermometer immedi- 
ately after collection inside small holes drilled into the core at 2 to $10 \mathrm{~cm}$ intervals. Thereafter, Core A was cut into 1 to $20 \mathrm{~cm}$ sections, and these were placed into clean polyethylene boxes. Ice segments were transported to the ship and melted in the dark at $4^{\circ} \mathrm{C}$. The salinity of the melted segments was measured with a WTW 190 conductometer. Subsamples (30 to $50 \mathrm{ml}$ ) were analysed for $\mathrm{NO}_{2}, \mathrm{PO}_{4}, \mathrm{NO}_{3}$ and $\mathrm{SiO}_{2}$ using automated nutrient-analysis procedures (Grasshoff et al. 1983). The remainder of the melted segments (70 to $1500 \mathrm{ml}$ ) was filtered onto pre-combusted Whatman GF/F filters and used for the determination of POC and PON with a CARLO ERBA NA 1500 CHN-Analyzer (Verardo et al. 1990).

Ice Core B was used for the microscopical investigation of bacteria, algae and exopolymer particles and for the determination of algal pigments. Sections (1 to $20 \mathrm{~cm}$ ) of this ice core were melted in the dark at $4^{\circ} \mathrm{C}$ with an addition of $0.2 \mu \mathrm{m}$-filtered seawater to avoid osmotic stress (Garrison \& Buck 1986, Spindler \& Dieckmann 1986). Blanks of the filtered seawater were taken at each station and treated as for the ice samples; the concentrations of all parameters (cell counts, exopolymer particles and algal pigments) in the blanks were insignificant. Immediately after the ice samples had melted, two $100 \mathrm{ml}$ subsamples were fixed with $0.2 \mu \mathrm{m}$-filtered borax-buffered formalin $(1 \%$ final conc.); 30 to $50 \mathrm{ml}$ of the first subsamples were filtered onto a black polycarbonate filter $(0.2 \mu \mathrm{m})$, stained with DAPI and mounted on a microscope-slide (Porter \& Feig 1980). From this slide the total bacterial number was calculated from at least 400 cells counted on a minimum of 20 fields with a Zeiss Axiovert 135 microscope using UV excitation. The second subsample was used for the determination of the abundance of centric and pennate diatoms. Samples were counted in settling chambers (Utermöhl 1958) following the recommendations of the Baltic Marine Environment Protection Commission (1988).

Determination of exopolymer particles followed the method of Alldredge et al. (1993) for the determination of so-called transparent exopolymer particles (TEP). However, because TEP is a term primarily used for pelagic particles formed by coagulation of dissolved precursors, the particles observed in the present study are more generally referred to as exopolymer particles because of their unknown mode of formation. For their determination, 30 to $50 \mathrm{ml}$ unfixed subsamples of melted ice segments were filtered carefully onto polycarbonate filters (pore size $0.4 \mu \mathrm{m})$ supported with backing filters with a pressure difference of $<0.1$ bar. Samples were stained with a $0.2 \mu \mathrm{m}$ pre-filtered solution of the polysaccharid-specific dye Alcian Blue and mounted on microscope slides (Alldredge et al. 1993). The relative cover of total exopolymer particle area on the filters was low (average $<1 \%$ ). Exopolymer particle abundance and size were measured semi-automatically at $400 \times$ magnification with a Leitz Aristoplan microscope connected to a Sony DXP-CCD video camera. A minimum of 500 exopolymer particles were videotaped and the videoframes were digitised. Contour lines of digitised exopolymer particle images were traced manually and the area of individual particles was determined with a LEICA QWIN 500 MC imageanalysis system. Individual exopolymer particle areas were converted to equivalent spherical diameters (ESD), which were assigned to 8 logarithmically increasing size classes ranging from 3 to $60 \mu \mathrm{m}$ ESD.

Particle size distributions are often described by power relations of the type $N=\mathrm{k} d_{\mathrm{p}}{ }^{-\beta}$, or $\mathrm{d} N / \mathrm{d}\left(d_{\mathrm{p}}\right)=$ $\mathrm{k} d_{\mathrm{p}}^{-(\beta+1)}$, where $\mathrm{d} N$ is the number of particles per unit volume in the size range $d_{\mathrm{p}}$ to $\left\{d_{\mathrm{p}}+\mathrm{d}\left(d_{\mathrm{p}}\right)\right\}$ (e.g. McCave 1984). The constant $\mathrm{k}$ depends on the concentration of the particles, and $\beta$ describes the size distribution of the particles; the smaller the $\beta$, the larger the fraction of large particles. A $\beta$ of 3 denotes equal particle volumes in the logarithmically increasing size classes (McCave 1984). We estimated $\beta+1$ values from the regressions of $\log \left\{\mathrm{d} N / \mathrm{d}\left(d_{\mathrm{p}}\right)\right\}$ versus $\log \left\{d_{\mathrm{p}}\right\}$. The magnitude of $\beta+1$ allows comparison of exopolymer particle size frequencies of different stations and environments.

The rest of the meltwater of the sections of Ice Core B was used for the determination of chlorophyll $a(\operatorname{chl} a)$ and pheopigments. Subsamples (200 to $2300 \mathrm{ml}$ ) were filtered onto Whatman GF/F filters and analysed fluorometrically with a Turner Designs 10-AU digital fluorometer according to Arar \& Collins (1992).

Under-ice water was sampled at all locations through drill holes using a polyethylene tube (internal diameter $4.0 \mathrm{~cm}$ ) with a valve at one end. The other end of the tube (equipped with a $8 \mathrm{~kg}$ weight) was lowered into the water with the valve open. At a depth of $10 \mathrm{~m}$, the valve was closed and the tube with the trapped water was retrieved. All parameters mentioned above were also determined for these integrated (0 to $10 \mathrm{~m}$ ) water samples.

Based on the temperature and salinity measurements of Core A, brine salinity was calculated as a function of ice temperature (Assur 1958) and brine volume as a function of ice temperature and ice bulk salinity (Frankenstein \& Garner 1967, Leppäranta \& Manninen 1988). Only non-parametric statistics were used for data analysis because of the high variability and the non-normal distributions of the data. Spearman rank-correlations were used to determine relationships between biogenic parameters. For testing significant differences between median values, the Kruskal-Wallis test was applied (Sachs 1984). 


\section{RESULTS}

\section{Physico-chemical parameters}

Drifting pack ice was sampled at 5 stations in the marginal ice zone of the East Greenland Current (Fig. 1). Ice thickness varied between $10 \mathrm{~cm}$ (Stn 277-2) and $304.5 \mathrm{~cm}$ (Stn 280), and ice temperatures between -8.0 and $-1.5^{\circ} \mathrm{C}$ (Fig. 2A). Strong temperature gradients were observed in the upper parts of the ice, whereas temperatures in the lower parts were more homogenous with values close to the freezing temperature of seawater.

Sea-ice bulk salinities ranged between 0.1 and 12.3 (Fig. 2B). Based on ice thickness and salinity profiles, ice cores were pooled into 3 different classes: young sea ice (YSI; ice thickness 10 to $38 \mathrm{~cm}$, salinity 5.7 to
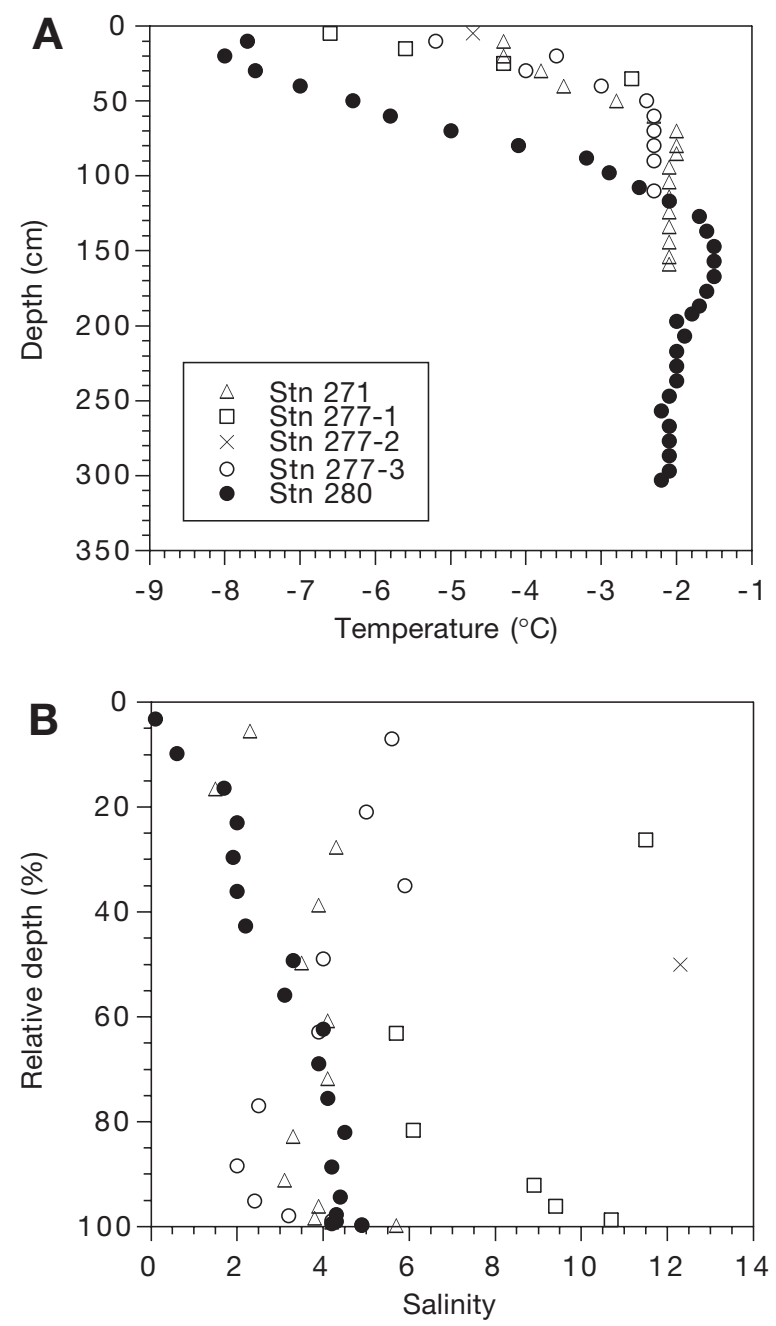

Fig. 2. (A) Vertical temperature profiles in sea ice floes. (B) Vertical profiles of sea-ice bulk salinity; note relative scale on $y$-axis
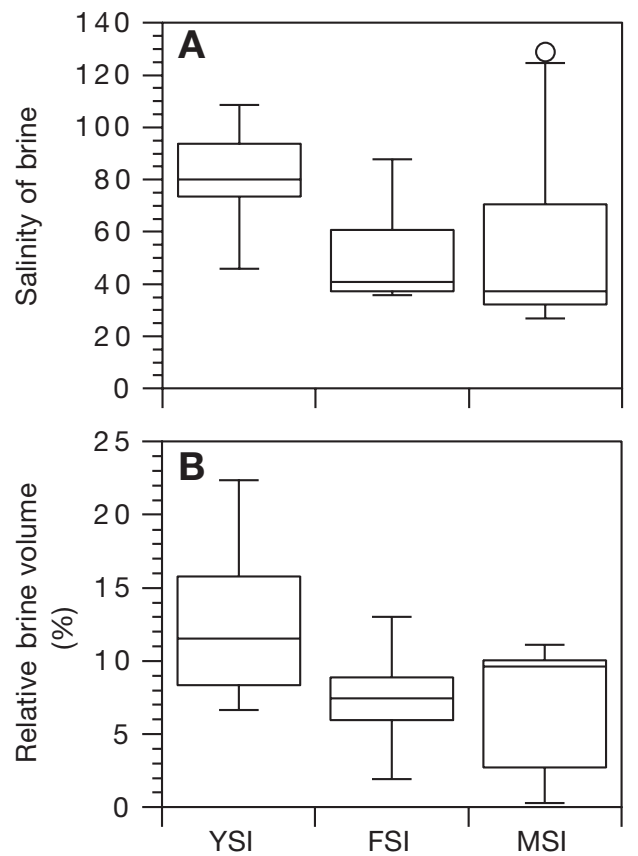

Fig. 3. (A) Box plots of brine salinity (calculated after Assur 1958). (B) Box plots of relative brine volume (calculated after Frankenstein \& Garner 1967 and Leppäranta \& Manninen 1988). YSI: young sea ice, FSI: first-year sea ice, MSI: multiyear sea ice. Box plots show total data range, 25 to $75 \%$ quartile range, and median. Single data points were marked as outliers when they exceeded a value of $V=U Q+1.5 \times I Q D$ (where $U Q$ is upper quartile, and $I Q D$ is interquartile distance)

12.3) was sampled in recently refrozen leads at Stns 277-1 and 277-2 (= nilas ice), first-year sea ice (FSI; ice thickness 143 to $193 \mathrm{~cm}$, salinity 1.5 to 5.9) at Stns 271 and 277-3, and multi-year sea ice (MSI; ice thickness 302 to $304.5 \mathrm{~cm}$, salinity 0.1 to 4.9) at Stn 280 . The highest bulk salinity was measured in nilas ice sampled at Stn 277-2; minimum bulk salinities occurred in the upper ice horizons at Stn 280.

Brine salinities, calculated as a function of ice temperature, ranged between 27.0 and 128.9. Median brine salinity was highest in YSI (median 79.9) followed by FSI (median 40.8) and MSI (median 37.4) (Fig. 3A). The relative brine volume (calculated as a function of ice temperature and bulk salinity) varied from $<1.0$ to $22.4 \%$. The highest values occurred in YSI (median $13.2 \%$ ), minimum brine volumes were observed in MSI (median 9.6\%) (Fig. 3B).

Median concentrations of $\mathrm{NO}_{2}, \mathrm{PO}_{4}$ and $\mathrm{NO}_{3}$ were highest in YSI followed by FSI and MSI (Fig. 4A-C). Median $\mathrm{SiO}_{2}$ concentrations were similar in all ice types and in the under-ice water (Fig. 4D). Median concentrations of $\mathrm{NO}_{3}$ in the different ice classes (total range $<0.1$ to $1.7 \mu \mathrm{M}$ ) were lower than water values (total range 1.5 to $3.0 \mu \mathrm{M}$ ). 
Table 1. Biological parameters of the different environments (range with median values in parentheses). $\beta+1$ : slope of size spectra, for definition see text

\begin{tabular}{|lcccc|}
\hline Parameter & Young sea ice & First-year sea ice & Multi-year sea ice & Water \\
\hline Particulate organic carbon $\left(\mathrm{mg} \mathrm{l}^{-1}\right)$ & $0.27-1.46(1.07)$ & $0.25-6.39(0.63)$ & $0.23-5.58(0.88)$ & $0.10-0.28(0.19)$ \\
Particulate organic nitrogen $\left(\mathrm{mg} \mathrm{l}^{-1}\right)$ & $0.04-0.31(0.16)$ & $0.03-0.54(0.06)$ & $0.01-0.34(0.06)$ & $0.02-0.05(0.03)$ \\
Molar C: $\left.\mathrm{N} \mathrm{ratio}_{\text {Chorophyll } \mathrm{a}\left(\mathrm{\mu g} \mathrm{l}^{-1}\right)}\right)$ & $4.0-10.7(6.0)$ & $6.3-19.5(12.4)$ & $12.3-50.2(17.4)$ & $5.7-7.0(6.9)$ \\
Pheopigments $\left(\mathrm{\mu g} \mathrm{l}^{-1}\right)$ & $1.0-17.1(6.7)$ & $0.1-10.2(2.1)$ & $0.1-12.1(1.0)$ & $0.3-0.8(0.5)$ \\
Pheopigment:chlorophyll a ratio & $0.4-3.8(1.7)$ & $0.1-1.7(0.4)$ & $0.1-3.2(1.0)$ & $0.2-0.4(0.2)$ \\
Pennate diatoms $\left(10^{3} \mathrm{cells} \mathrm{l}^{-1}\right)$ & $0.2-1.5(0.3)$ & $0.1-0.5(0.2)$ & $0.1-3.1(0.7)$ & $0.4-0.5(0.5)$ \\
Centric diatoms $\left(10^{3} \mathrm{cells}^{-1}\right)$ & $2.6-742.0(140.2)$ & $4.2-1323.9(234.0)$ & $1.8-2049.2(456.2)$ & $4.5-45.0(5.9)$ \\
Bacteria $\left(10^{9}{\left.\mathrm{cells} \mathrm{l}^{-1}\right)}^{-1}\right)$ & $0.21-1.20(0.31)$ & $0.22-0.94(0.47)$ & $0.11-2.49(0.37)$ & $0.26-1.06(0.34)$ \\
Exopolymer particles $\left(10^{6} \mathrm{particles}^{-1}\right)$ & $1.43-4.65(3.17)$ & $2.28-10.42(4.15)$ & $0.43-14.93(4.90)$ & $0.50-8.24(0.56)$ \\
Exopolymer particles $\left(\mathrm{cm}^{2} \mathrm{l}^{-1}\right)$ & $2.0-10.9(5.9)$ & $1.6-16.2(6.9)$ & $0.6-9.2(4.6)$ & $0.2-0.9(0.6)$ \\
$\beta+1$ & $1.6-2.2(1.7)$ & $1.4-2.7(2.0)$ & $1.6-3.2(2.3)$ & $2.2-3.2(2.2)$ \\
\hline
\end{tabular}

\section{Biogenic parameters}

Biogenic parameters measured in the different ice classes and in the under-ice water are summarised in Table 1. Median POC values of sea ice samples were relatively similar in all ice types and exceeded the under-ice water values by factors of 3.3 to 5.6 (Fig. 5A). Median PON values were highest in YSI and decreased with increasing age of the sampled ice (Fig. 5B), resulting in an increase of the median $\mathrm{C}: \mathrm{N}$ ratios with increasing age of the sea ice (Fig. 5C, Table 1).
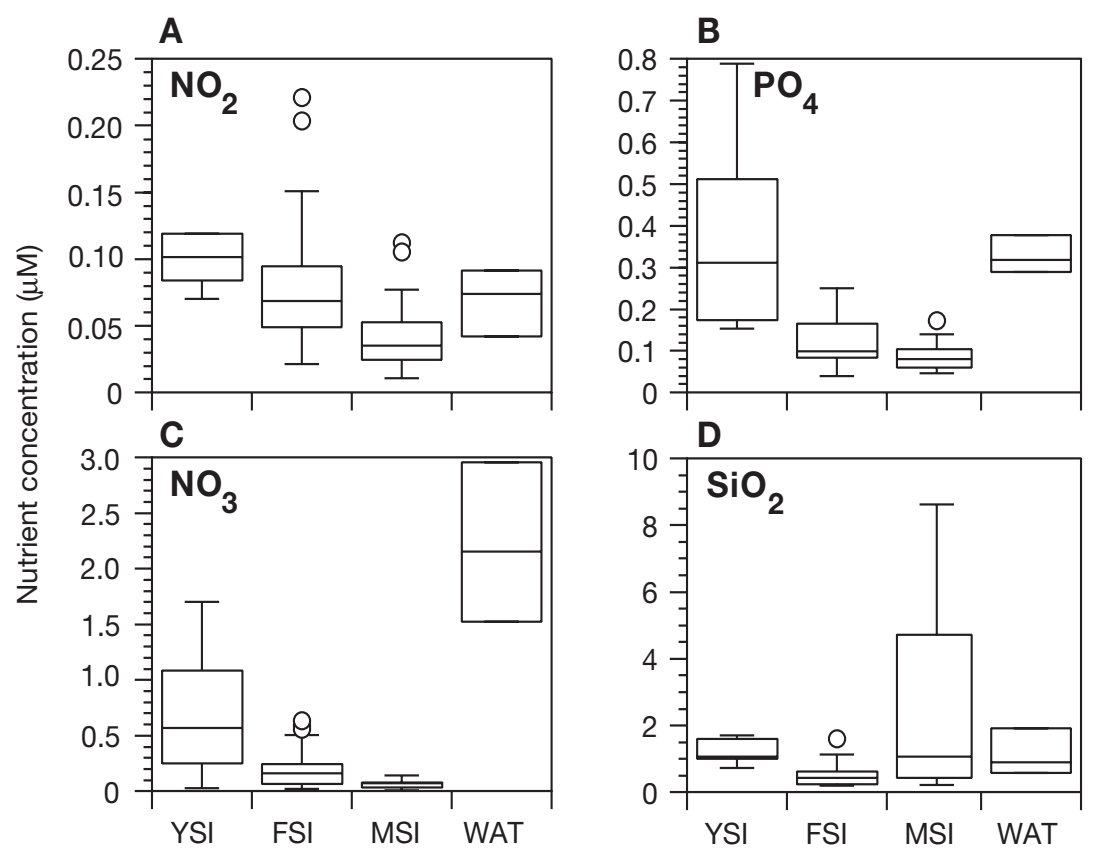

Fig. 4. Box plots of nutrient concentrations. YSI: young sea ice; FSI: first-year sea ice; MSI: multi-year sea ice; WAT: under-ice water. Box plots calculated as in Fig. 3
Chl a concentrations of the sea ice showed large vertical variations, with peaks occurring both at the bottom and in the interior of the ice (data not shown). The maximum chl a concentration (17.1 $\mu g \mathrm{l}^{-1}$ ) was observed in the interior of YSI (Stn 277-1), which also had the highest median chl a value $\left(6.7 \mu \mathrm{g} \mathrm{l}^{-1}\right)$. Median chl a concentrations in FSI $\left(2.1 \mu \mathrm{g} \mathrm{l}^{-1}\right)$ and MSI $(1.0 \mu \mathrm{g}$ $\mathrm{l}^{-1}$ ) decreased in order of increasing ice age. Chl a concentrations in the under-ice water were low, with a median of $0.5 \mathrm{\mu g}^{-1}$ (Fig. 5D). The pheopigment:chl a ratio was highest in the MSI and water samples, with median values of 0.7 and 0.5 , respectively.

In this study, exopolymer particle concentrations are reported in 2 ways: as exopolymer particle abundance (particles $\mathrm{l}^{-1}$ ) and exopolymer particle area $\left(\mathrm{cm}^{2} \mathrm{l}^{-1}\right)$. High concentrations of particles were found in all sea ice classes (Fig. 5E,F, Table 1). Exopolymer particle abundance in sea ice varied between $0.43 \times 10^{6}$ and $14.93 \times$ $10^{6}$ particles $\mathrm{l}^{-1}$, the area of the exopolymer particles between 0.6 and $16.2 \mathrm{~cm}^{2} \mathrm{l}^{-1}$. Vertical profiles of the concentrations showed peaks in different layers, with maximum exopolymer particle concentrations always occurring in the interior of the ice (Fig. 6). With the exception of the upper $80 \mathrm{~cm}$ ice layer of the MSI (Stn 280), exopolymer particle abundance and area in sea ice were 1 order of magnitude higher than in the under-ice water (Fig. 6, Table 1). This large difference is also reflected in the median exopolymer particle concentrations (Fig. 5E,F), which were considerably 

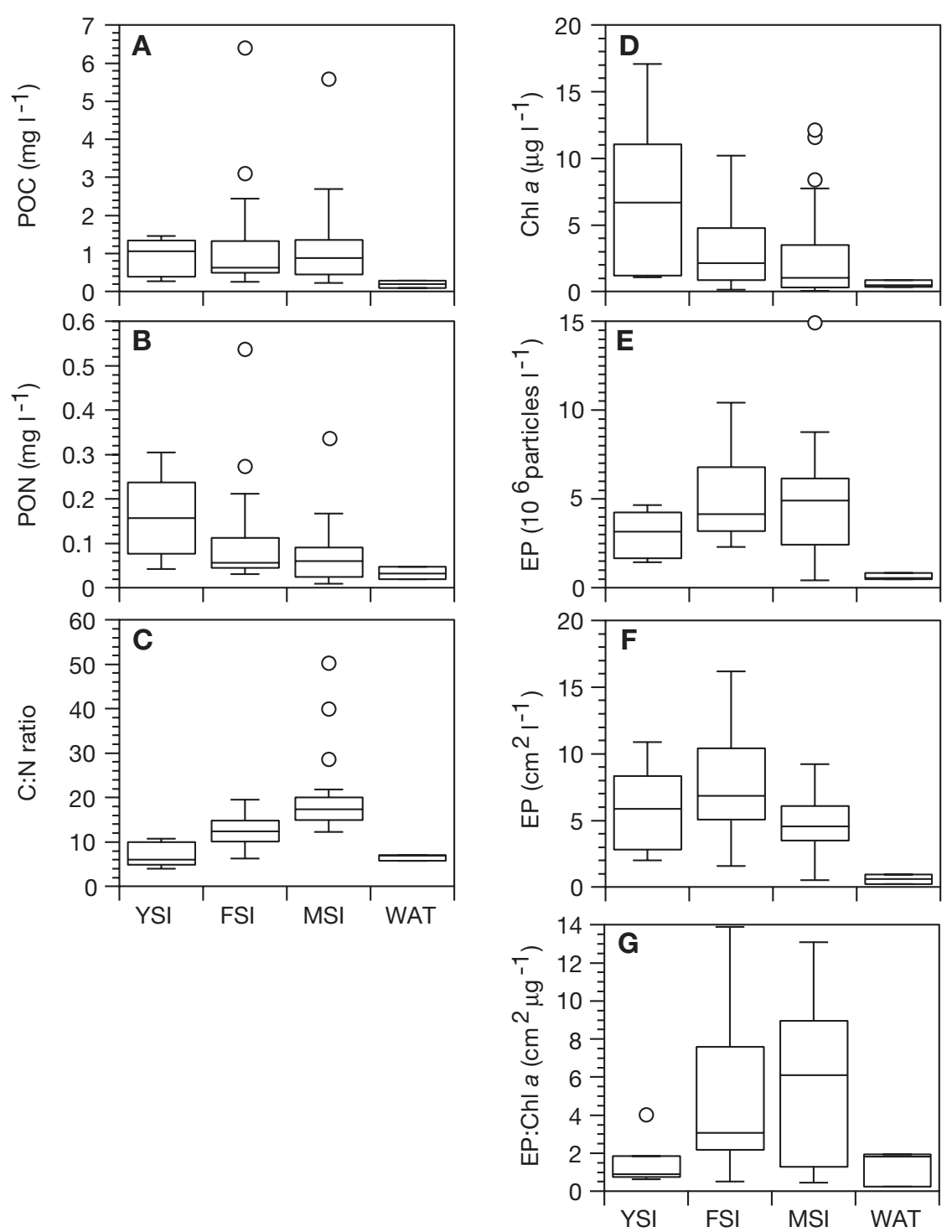

Fig. 5. Box plots of (A) particulate organic carbon (POC), (B) particulate organic nitrogen (PON), (C) molar POC:PON ratio = C:N ratio, (D) chl a concentration, (E) abundance of exopolymer particles (EP), (F) area of exopolymer particles (EP), and (G) exopolymer particle area:chl a ratio (EP:Chl a) in the different environments. Box plots calculated as in Fig. 3; abbreviations as in Fig. 4

higher in the sea ice environments than in the underice habitat. Differences in the median concentrations were statistically significant for exopolymer particle area only (exopolymer particle area: Kruskall-Wallis test, $p=0.0209$; exopolymer particle abundance: Kruskall-Wallis test, $\mathrm{p}>0.05)$. The median exopolymer particle:chl a ratio increased with increasing age of the sampled ice floes from YSI through FSI to MSI (Fig. 5G), indicating enrichment of exopolymer particles relative to autotrophs in the sea ice habitat over time. The abundance of exopolymer particles was negatively correlated with size and followed a power law relationship, except for a few samples in which the smallest size class appeared to be under-represented.
The slopes of the size distributions were relatively flat, with $\beta+1$ values in the range of 1.4 to 3.2 in the icecore sections and 2.2 to 3.2 in the under-ice water (Table 1). Relative exopolymer particle size frequencies for the pooled data of YSI, FSI, MSI and water showed flat size distributions, with $\beta+1$ values in the range of 1.9 to 2.3 (Fig. 7), indicating a significant proportion of larger exopolymer particles in both sea ice and water.

The most important primary producers in the sea ice samples were pennate diatoms, whose abundances showed large vertical variations (data not shown). Median pennate diatom abundance in ice cores was

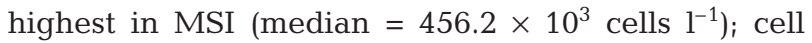




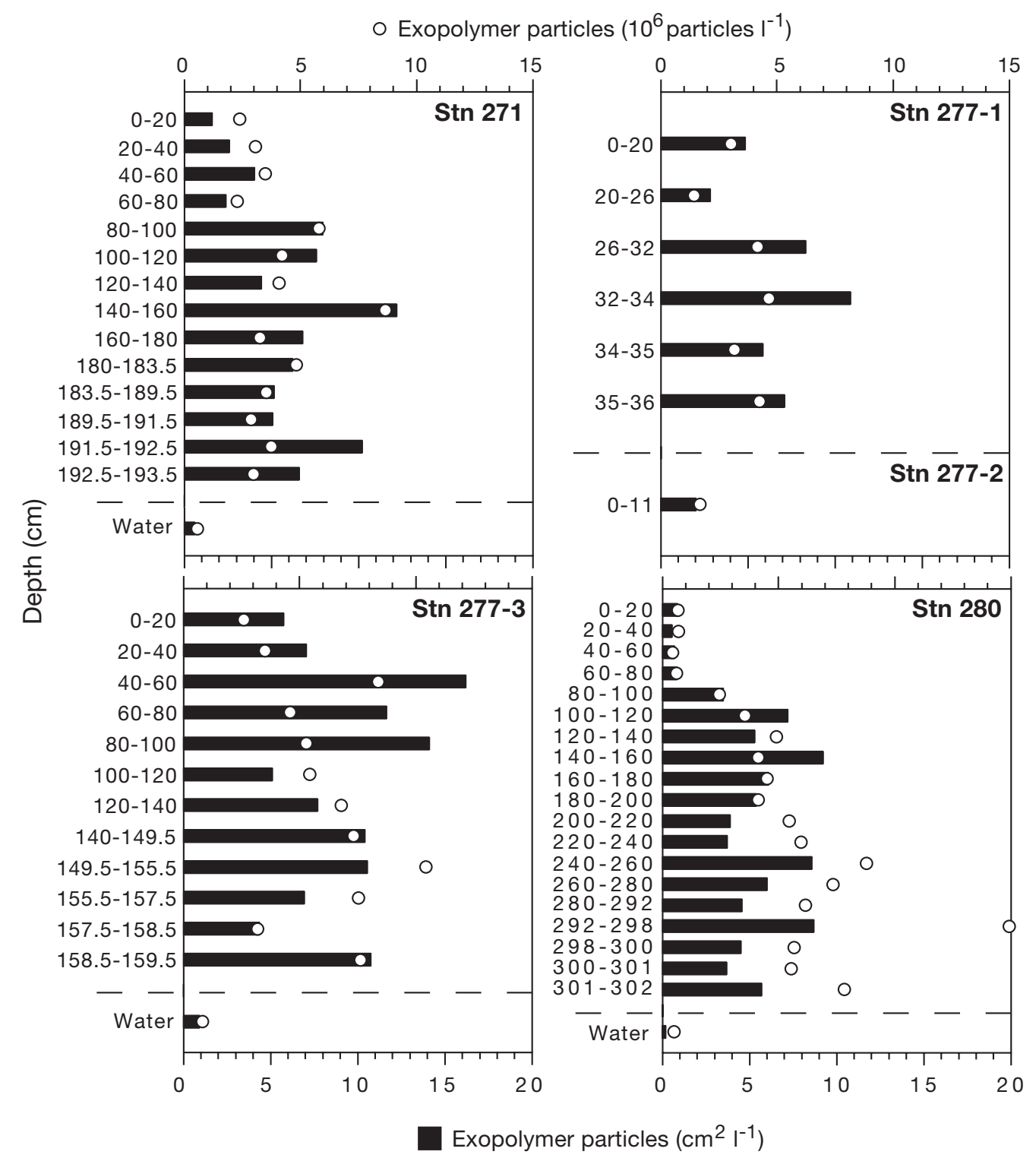

Fig. 6. Vertical distribution of exopolymer particles: concentration and area in sea ice and under-ice water

numbers were lower in FSI and YSI (Table 1). The abundance of pennate diatoms in sea ice was significantly correlated with ice depth (Table 2). With the exception of YSI, the abundances of centric diatoms in sea ice were much lower than the cell numbers of pennate diatoms. Only in YSI and in under-ice water samples were centric diatoms more abundant than pennate species (Table 1).

Bacterial concentrations in sea ice showed large vertical variability (factor of 25). Minimum concentrations $\left(0.11 \times 10^{9}\right.$ bacteria $\left.\mathrm{l}^{-1}\right)$ were observed in the upper horizons of the MSI; the highest total bacterial numbers $\left(2.49 \times 10^{9}\right.$ bacteria $\left.\mathrm{l}^{-1}\right)$ occurred in the bottom sections of the same ice class (data not shown). Bacterial concentrations (pooled sea ice data) were significantly correlated with ice depth (Spearman rank-correlation; rho $=0.424 ; p=0.0033$ ). However, YSI and FSI showed internal maxima of bacterial abundances. Median bacterial concentrations of all ice types and under-ice water were relatively similar and varied from 0.31 to $0.47 \times 10^{9}$ cells $^{-1}$ (Table 1 ).

Spearman rank-correlations were used to explore the relationships between parameters measured in sea ice segments obtained exclusively from the B cores (Table 2), because of different lengths and subsequently different vertical resolutions of Cores A and B. Exopolymer particle concentrations in the sea ice correlated significantly with chl a concentrations as well 


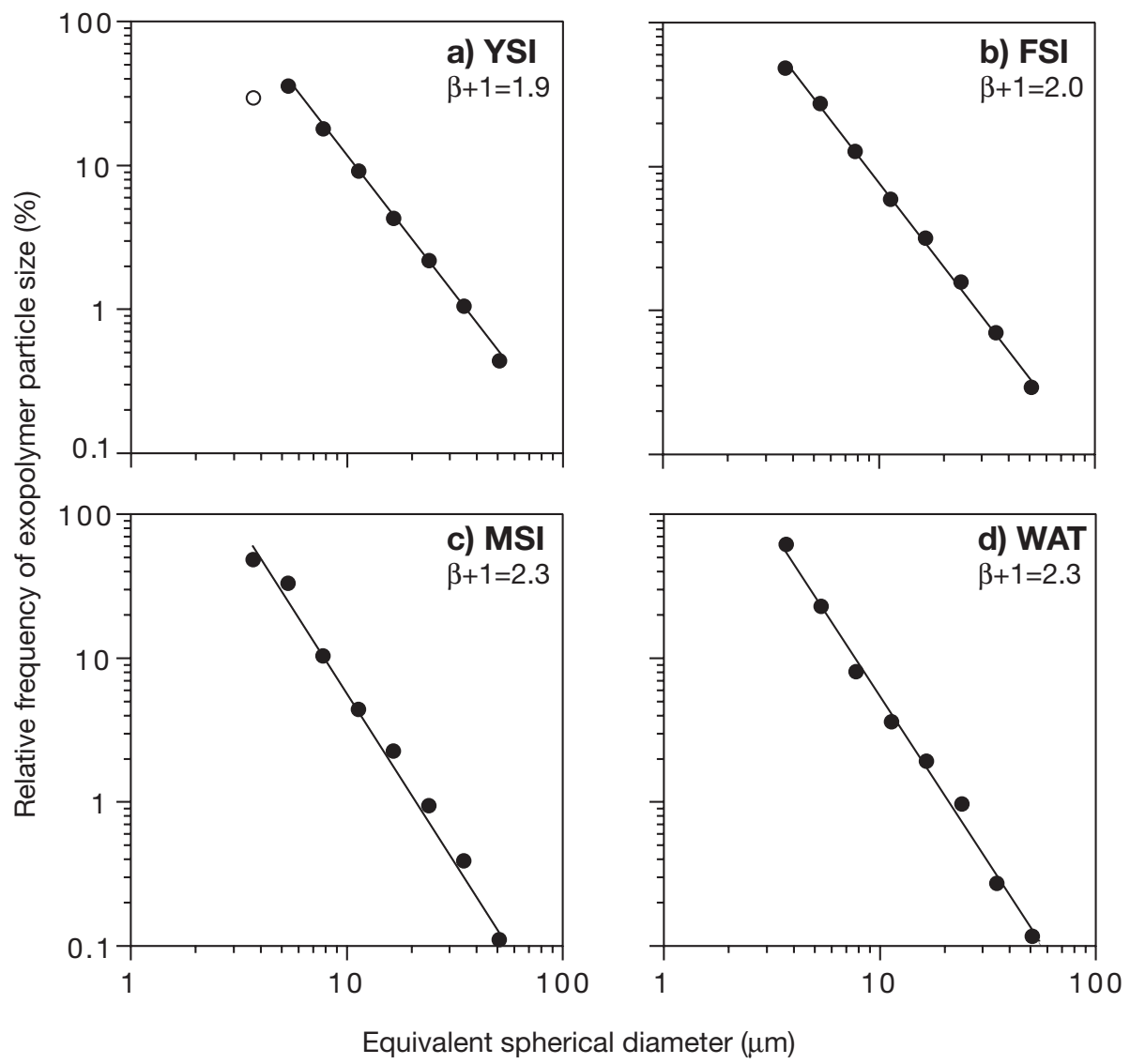

Fig. 7. Relative size frequencies of exopolymer particles (pooled data) in (a) young sea ice (YSI), (b) first-year sea ice (FSI), (c) multi-year sea ice (MSI), and (d) under-ice water (WAT). Black data points only were used for the regression lines and determination of $\beta+1$ values (slopes of regression lines, for definition see text)

as with the abundances of pennate diatoms, centric diatoms and bacteria (Table 2). The ratio of diatom: bacteria abundance showed a highly significant correlation with exopolymer particle area (Spearman rankcorrelation, rho $=0.477 ; \mathrm{p}=0.0007$ ).

\section{DISCUSSION}

\section{Discussion of method}

Our study provides a first comparison of exopolymer particle concentrations in natural Arctic pack ice of varying age. The determination of exopolymeric substances in sea ice, however, is subject to methodological problems (Krembs \& Engel 2001), which we attempted to overcome with a combination of sea ice biological and planktological methods. In this study, exopolymer particle concentrations and size distributions were determined in ice samples melted by addition of $0.2 \mu \mathrm{m}$ filtered seawater (Garrison \& Buck 1986, Spindler \& Dieckmann 1986). Concentrations of dissolved organic carbon (DOC) in Arctic sea ice are nor- mally much higher than in water (Bunch \& Harland 1990, Thomas et al. 1995), and thus the addition of the sterile-filtered seawater reduced not only exopolymer particle concentrations, but also DOC concentrations in the meltwater. The dilution step reduces encounter rates of DOC as well as exopolymer particles, and is therefore assumed to reduce both the abiotically formation of exopolymer particles from dissolved precursors (Chin et al. 1998, Passow 2000, 2002) and coagula-

Table 2. Spearman rank-correlations of biological parameters (bulk concentrations) for pooled ice core data. Values in bold are statistically significant $(\mathrm{p}<0.01, \mathrm{n}=49$ ). Chl $a$ : chlorophyll $a_{\text {; }}$ PHEO: pheopigments; PEN: pennate diatoms; CEN: centric diatoms; BACT: bacteria; EP: exopolymer particles

\begin{tabular}{|lcccccc|}
\hline Parameter & Depth & Chl a & PHEO & PEN & CEN & BACT \\
\hline Chl $a$ & 0.371 & & & & & \\
PHEO & $\mathbf{0 . 6 1 1}$ & 0.334 & & & & \\
PEN & $\mathbf{0 . 3 7 5}$ & 0.326 & $\mathbf{0 . 5 0 0}$ & & & \\
CEN & 0.139 & $\mathbf{0 . 8 0 7}$ & 0.248 & 0.211 & & \\
BACT & $\mathbf{0 . 4 2 4}$ & 0.362 & $\mathbf{0 . 5 0 6}$ & $\mathbf{0 . 5 0 9}$ & 0.180 & \\
EP (area) & 0.350 & $\mathbf{0 . 6 2 1}$ & 0.331 & $\mathbf{0 . 4 8 8}$ & $\mathbf{0 . 4 6 3}$ & $\mathbf{0 . 5 1 1}$ \\
\hline
\end{tabular}


tion of exopolymer particles into larger particles (Passow et al. 1994, Schuster \& Herndl 1995, Mari \& Burd 1998, Stoderegger \& Herndl 1999). The use of filtered seawater also buffered salinity changes in the melting sea ice and reduced osmotic stress to the organisms (Garrison \& Buck 1986, Spindler \& Dieckmann 1986). We assume, therefore, that our melting method minimised EPS production by organisms, which can respond to osmotic stress by enhanced excretion of polymeric substances (Decho 1990, Hoagland et al. 1993). However, loss terms such as disintegration of exopolymer particles can also bias results. For example, Riebesell et al. (1991) reported monospecific diatom aggregates on the subsurface of Antarctic sea ice which were presumed to have formed inside the brine-channel system. We did not observe this type of monospecific aggregates, but assume that disaggregation did not occur, since a large contribution of relatively large particles was observed in all samples. As melting of ice samples generally destroys the natural structure of the sea ice habitat and allows free interaction of particles, differences between the actual and observed exopolymer particle abundances and characteristics in sea ice samples remain possible (Krembs \& Engel 2001). Conclusively, the applied method for the determination of exopolymer particles in sea ice minimised artificial exopolymer particle formation, but artifacts in particle abundance and characteristics cannot be totally ruled out.

\section{Producers of exopolymer particles}

Diatoms are considered important producers of EPS in pelagic and benthic habitats (Decho 1990, Mopper et al. 1995, Smith \& Underwood 1998). Especially benthic pennate diatoms produce copious amounts of exopolymeric substances that serve in the adhesion and the motility of the organisms (Hoagland et al. 1993, Cooksey \& Wigglesworth-Cooksey 1995). Krembs \& Engel (2001) suggested pennate diatoms as the dominant producers of exopolymer particles in bottom communities of Arctic pack ice during summer. In our study, sea ice exopolymer particles were correlated with the abundances of diatoms and bacteria, which may both significantly contribute to the EPS pool in sea ice. To estimate the importance of the 2 groups for the accumulation of exopolymeric substances in sea ice, we calculated the daily production rates of sea ice diatoms and bacteria using cell-specific EPS production rates of temperate epipelic diatoms (6.31 to $31.46 \mathrm{pg}$ glucan equivalents cell $^{-1} \mathrm{~d}^{-1}$; average $=$ $18.01 \mathrm{pg}$ glucan equivalents cell ${ }^{-1} \mathrm{~d}^{-1}$ : Smith \& Underwood 2000) and temperate planktonic bacteria (4 amol $\mathrm{C} \mathrm{cell}^{-1} \mathrm{~h}^{-1}$ : Stoderegger \& Herndl 1999). Rates of tem- perate species were used because of a lack of data on cold-adapted and sympagic species. Neglecting temperature effects and assuming a carbon:glucan ratio of 0.4 , estimated EPS production of sea ice diatoms was on average $3.6 \mu \mathrm{g} \mathrm{C}^{-1} \mathrm{~d}^{-1}$ (range 0.1 to $18.7 \mu \mathrm{g} \mathrm{Cl}^{-1}$ $\left.\mathrm{d}^{-1}\right)$, and estimated bacterial EPS production in sea ice averaged only $0.7 \mu \mathrm{g} \mathrm{Cl}^{-1} \mathrm{~d}^{-1}$ (range 0.1 to $2.9 \mu \mathrm{g} \mathrm{Cl}^{-1}$ $\mathrm{d}^{-1}$ ). The diatom EPS production:bacterial EPS production ratio was high, with an average of 6.1 (range 0.05 to 40.9). This high ratio and the striking dominance of pennate forms imply that pennate diatoms were the primary source of exopolymeric substances in the sea ice under investigation. This idea is also supported by the highly significant positive correlation of the diatom:bacteria abundance ratio with the exopolymer particle area. However, interactions between bacteria and exopolymer particles are complex and the influence of bacteria on the EPS pool in sea ice remains unclear. Bacteria may act in the production, modification and degradation of exopolymer particles in various ways (Passow 2002). Active bacteria produce capsular material, which is constantly renewed and released to the environment (Stodderegger \& Herndl 1999). Attached sympagic bacteria may produce EPS, which serves in the adhesion of the cells to various surfaces, e.g. ice crystal surfaces, algae and detrital particles (Junge et al. 2001). Bacteria may also modify the DOC-pool and thus influence its potential for spontaneous assembly into polymeric gels (Chin et al. 1998). On the other hand, bacteria attached to particles show high metabolic rates and may act in the degradation of exopolymer particles (Smith et al. 1992, review by Simon et al. 2002).

\section{Exopolymer particle concentrations and characteristics}

In this study, high exopolymer particle concentrations were observed in young, first-year and multi-year sea ice, exceeding under-ice water values by 1 order of magnitude. Using enumeration techniques similar to those in the present study, Krembs \& Engel (2001) recorded exopolymer particle concentrations between below detection and $16 \mathrm{~cm}^{2} \mathrm{l}^{-1}$, with a median value of $2.9 \mathrm{~cm}^{2} \mathrm{l}^{-1}$ for the undermost $10 \mathrm{~cm}$ of Arctic pack ice in the Laptev Sea during summer. Exopolymer particle concentrations in the present study showed a similar range, but median values of all ice types exceeded the median value given by Krembs \& Engel (2001) by a factor of 2 to 3 . This can be explained by our high values for the ice interior, which was not studied in the other investigation. The same authors found a distinct size pattern of sea ice-derived exopolymer particles, with a higher contribution of relatively large particles. 
Their calculated mean $\beta+1$ value of 1.86 agrees well with the average value in this study (2.1). The difference from values commonly reported for pelagic environments $(\beta+1 \sim 4)$, demonstrates that sea ice contains a large fraction of relatively large particles, indicating differences in environmental factors affecting processes of exopolymer particle formation (coagulation) and losses (grazing, disaggregation) in sea ice and the pelagic realm. We assume that the high proportions of relatively large particles represent fragments of biofilms which coated the surface of brine channel walls. The occurrence of sympagic biofilms has been suggested by Thomas \& Dieckmann (2002). However, in the present study also, under-ice water samples showed reduced $\beta+1$ values (range 2.2 to 3.2 ) compared to particle size spectra determined in other pelagic studies. We therefore assume that the underice water samples of our study contained sea ice derived exopolymer particles and/or that the presence of shear stress in the sub-ice water layer increased coagulation of particles and thus reduced $\beta+1$ values in this particular habitat.

The newly formed nilas ice sample already showed increased exopolymer particle abundance compared to under-ice water. Particles are incorporated into sea ice by various physical processes (e.g. Shen \& Ackermann 1990, Grossmann \& Dieckmann 1994, Spindler 1994). Gradinger \& Ikävalko (1998) showed that the selectivity of incorporation processes of algae into newly forming sea ice is immense, and proposed that not only particle size (Penny \& Sullivan 1990) but also surface characteristics of the particles (e.g. stickiness) are responsible for different incorporation rates. Gradinger \& Ikävalko (1998) calculated an enrichment index, $I_{S}$, which allows the comparison of particle concentrations in newly formed sea ice and water based on salinity and concentration data. An $I_{S}$ value of 1 indicates no differences in concentrations between samples; increased values demonstrate elevated concentrations in the ice sample compared to that of the underlying water. Using their approach, we calculated enrichment indices for the abundances of pennate diatoms $\left(I_{S}=0.5\right)$, bacteria $\left(I_{S}=1.8\right)$, and exopolymer particles $\left(I_{S}=5.6\right)$ in the nilas ice sample at Stn $277 \mathrm{~b}$ (thickness $=11 \mathrm{~cm}$ ). These values are relatively low compared to the enrichment indices of 7 for bacteria and 212 for pennate diatoms reported by Gradinger \& Ikävalko (1998). Nevertheless, the data show that exopolymer particles were already significantly enriched at the initial stage of sea ice formation. Grossmann \& Dieckmann (1994) proposed that bacteria are incorporated into newly forming sea ice via attachment to algae and algal mucus. Since exopolymeric substances are sticky and serve in the coagulation of particles (Passow et al. 1994, Engel 2000), we propose that the presence of exopolymer particles in the seawater from which the ice forms might also influence the incorporation of other particles (organisms and sediments) into newly forming sea ice, e.g. by enhanced adhesion of particles to crystal surfaces. However, the incorporation of exopolymeric substances as well as DOC into newly forming sea ice are poorly understood and need further investigation (Giannelli et al. 2001, Thomas et al. 2001).

Many studies have shown increased production of exopolymeric substances by planktonic and benthic algae under nutrient limitation, during senescence of algal blooms, and in response to different environmental stress factors (Decho 1990, Myklestad 1995, Corzo et al. 2000, Liu \& Buskey 2000, Staats et al. 2000). Aletsee \& Jahnke (1992) reported high concentrations of Alcian Blue-stainable mucus in sea ice algal cultures exposed to cold temperatures. During the summer-winter transition, rapidly decreasing light levels and the development of steep temperature and brine salinity gradients in ice floes create many challenges to the sympagic biota, which stimulate production of EPS (Thomas \& Dieckmann 2002, C. Krembs pers. comm.). In the present study, day lengths decreased by $~ 30 \mathrm{~min}$ $\mathrm{d}^{-1}$ and the ice showed strong vertical temperature gradients with minimum temperatures of $-8.0^{\circ} \mathrm{C}$. Cold temperatures were accompanied by high brine salinities ranging between $\sim 40$ and $\sim 130$ in the middle and upper parts of the ice, which could have affected EPS production of internal communities (Gradinger \& Zhang 1997, Gradinger 1999, Mock \& Gradinger 1999), explaining our observed internal exopolymer particle peaks.

In addition to cold temperatures and salinities, restricted nutrient availability in the ice interior (Cota et al. 1987, Smith et al. 1990, Gradinger et al. 1992) may have affected exopolymer particle production. Using bulk nutrient concentrations and brine volume calculations, we estimated nutrient concentrations in the sea ice brine, i.e. the concentrations to which the sympagic organisms were exposed. Nutrient concentrations in the sea ice brine were high (pooled ice data: $\mathrm{NO}_{2}+\mathrm{NO}_{3}>0.24 \mu \mathrm{M}, \mathrm{PO}_{4}>0.56 \mu \mathrm{M}$ and $\mathrm{SiO}_{2}>$ $2.4 \mu \mathrm{M})$ and exceeded half-saturation constants $\left(\mathrm{k}_{\mathrm{S}}\right.$ values) commonly reported for mixed natural phytoplankton assemblages (Sommer 1998). The data suggest that nutrients were not limiting sympagic algal production and that EPS production was not affected by nutritional limitation during the time of this investigation. Since EPS pools may also contain large fractions of refractory material (Hoagland et al. 1993), sea ice exopolymer particles may also accumulate over longer time-scales in different layers of the sea ice, and the high concentrations observed in our study may be old signals of previous situations of environmental and/or nutritional stress. Further studies in different 
seasons are necessary to determine if the bulk of the ice-associated exopolymer particles is produced and accumulated during the productive spring and summer seasons, when nutrients can be severely depleted (Gosselin et al. 1990, Cota et al. 1991), or if it is formed in response to the changing environmental conditions during the summer-winter transition. The accumulation of refractory material may also explain the poor relationship between median exopolymer particle concentrations and other median values of abiotic and biotic parameters in the different ice types. Despite distinct differences between median nutrient concentrations, C:N ratios and chl a values, reflecting the different environmental conditions in the 3 ice types observed, median concentrations of exopolymer particles in ice classes showed relatively little variation and did not resemble the variation in the other parameters. We interprete the good consistency of median exopolymer particle:chl $a$ ratios and median $\mathrm{C}: \mathrm{N}$ ratios as indication of an accumulation of exopolymer particles in older sea ice.

\section{Estimate of exopolymer particle carbon}

Integrated POC levels in the sea ice varied between 38.0 and $2808.9 \mathrm{mg} \mathrm{C} \mathrm{m}^{-2}$. Using the equation of Mari (1999) with TEP-C $\left(\mu g \mathrm{C} \mathrm{TEP}^{-1}\right)=0.25 \times 10^{-6} r^{2.55}$, where $r$ is the equivalent spherical radius of the (transparent) exopolymer particle $(\mu \mathrm{m})$ and $D$ is its fractal dimension, we calculated integrated exopolymer particle carbon values of between 7.3 and $564.8 \mathrm{mg} \mathrm{C} \mathrm{m}^{-2}$ sea ice. According to this calculation, the exopolymer particle carbon accounts for 16.0 to $32.1 \%$ (average $24.4 \%$ ) of the integrated POC values. We wish to stress that this is only a tentative estimate, because of problems in transferring the carbon content of the suspended laboratory-made TEP particles to the sea ice exopolymer particles. Exopolymer particles are a chemically diverse group, and chemical composition varies with species composition and the physiological state of the producers (Engel \& Passow 2001). Furthermore, POC was measured on GF/F filters with a pore size of approximately $0.7 \mu \mathrm{m}$, whereas exopolymer particles were quantified on $0.4 \mu \mathrm{m}$ pore-size polycarbonate filters, which may have resulted in an overestimation of the relative contribution of exopolymer particle carbon. Nevertheless, the data indicate that exopolymer particles represent an important, until now largely neglected, source of sea ice carbon. The potentially very high exopolymer particle carbon concentrations may have implications for the sympagic food web and may serve as a food source for iceassociated protozoans and metazoans during the long and unproductive winter season when the autotrophic standing stock is low and food sources become scarce. Furthermore, recent studies indicate that exopolymeric substances may have important functions in the structuring of the immediate environment of sympagic bacteria and diatoms. C. Krembs (pers. comm.) observed Alcian Blue-stainable mucus around diatoms in winter sea ice of the Chukchi Sea, and proposed that sympagic diatoms may produce EPS-rich microhabitats, which serve the organisms in extracelluar protection against high salinities and ice-crystal damage. Raymond et al. (1994) reported so-called ice-active substances (IAS) thought to be glycoproteins, which cause pitting of ice crystals and influence the optical properties of sea ice around diatoms.

\section{Conclusion}

Our data demonstrate that Arctic sea ice of different age harbours copious amounts of exopolymer particles with distinct size-frequency distributions. Tentative estimates of exopolymer particle carbon indicate that exopolymeric substances contribute significantly to the carbon pool in Arctic sea ice and may affect sympagic food-web structure and the turnover of organic carbon in the sea ice habitat. Assuming a low degradation of exopolymer particles in winter, significant amounts of exopolymer particles can be released to the water column during spring and summer, where they can affect formation of aggregates and subsequent sedimentation of sea ice carbon. Studies in the Southern Ocean (Herborg et al. 2001, Thomas et al. 2001) suggest that Antarctic sea ice also contains large amounts of exopolymeric substances, but detailed studies on sea ice polymeric substances in this region are lacking. Further studies are necessary to elucidate the ecological functions of EPS in both Arctic and Antarctic sea ice.

Acknowledgements. We thank the captain and crew of the RV 'Polarstern' for their cooperation during Cruise ARK XV-3, as well as all those who supported us at the ice stations. We would like to thank A. Lindfors and J. He for their help in the field, and B. Guerra and M. Lipizer for their help with the nutrient analysis. The valuable comments of C. Krembs and 3 anonymous referees on an earlier draft of the manuscript are gratefully acknowledged. The work of G.C. was funded by the Commission of the European Union (VEINS-project, contract MAS3-CT96-0070). This work was supported by the Deutsche Forschungsgemeinschaft (grant SP 377/9-1-3).

\section{LITERATURE CITED}

Aletsee L, Jahnke J (1992) Growth and productivity of the psychrophilic marine diatoms Thalassiosira antarctica Comber and Nitzschia frigida Grunow in batch cultures at temperatures below the freezing point of sea water. Polar Biol 11:643-647 
Alldredge A, Passow U, Logan B (1993) The abundance and significance of a class of large transparent organic particles in the ocean. Deep-Sea Res Part I Oceanogr Res Pap 40:1131-1140

Arar EJ, Collins GB (1992) In vitro determination of chlorophyll $a$ and pheophytin $a$ in marine and freshwater algae by fluorescence. Method 445.0. Methods for the determination of chemical substances in marine and estuarine environmental samples. US Environmental Protection Agency, Cincinnati, OH

Assur A (1958) Composition of sea ice and its tensile strength. Publ Natl Res Counc Can 598:106-138

Baltic Marine Environment Protection Commission (1988) Guidelines for the Baltic Monitoring Programme for the third stage, Part D. Biological determinands. Baltic Sea Environment Proceedings No. 27 D. The Finnish Government Printing Centre, Helsinki, p 28-53

Bunch JN, Harland RC (1990) Bacterial production in the bottom surface of sea ice in the Canadian subarctic. Can J Fish Aquat Sci 47:1986-1995

Carey AG (1987) Particle flux beneath fast ice in the shallow southwestern Beaufort Sea, Arctic Ocean. Mar Ecol Prog Ser 40:247-257

Chin WC, Orellana MV, Verdugo P (1998) Spontaneous assembly of marine dissolved organic matter into polymer gels. Nature 391:568-572

Cooksey KE, Wigglesworth-Cooksey B (1995) Adhesion of bacteria and diatoms to surfaces in the sea: a review. Aquat Microb Ecol 9:87-96

Corzo A, Morillo JA, Rodríguez S (2000) Production of transparent exopolymer particles (TEP) in cultures of Chaetoceros calcitrans under nitrogen limitation. Aquat Microb Ecol 23:63-72

Cota CF, Prinsenberg SJ, Bennett EB, Loder JW, Lewis MR, Anning JL, Watson NHF, Harris LR (1987) Nutrient fluxes during extended blooms of Arctic ice algae. J Geophys Res C Oceans 92(C2):1951-1962

Cota CF, Legendre L, Gosselin M, Ingram RG (1991) Ecology of bottom ice algae. I. Environmental controls and variability. J Mar Syst 2:257-277

Decho A (1990) Microbial exopolymer secretions in ocean environments: their role(s) in food webs and marine processes. Oceanogr Mar Biol Annu Rev 28:73-153

Engel A (2000) The role of transparent exopolymer particles (TEP) in the increase of apparent particle stickiness $(\alpha)$ during the decline of a diatom bloom. J Plankton Res 22: 485-497

Engel A, Passow U (2001) Carbon and nitrogen content of transparent exopolymer particles (TEP) in relation to their Alcian Blue adsorption. Mar Ecol Prog Ser 219:1-10

Engel A, Schartau M (1999) Influence of transparent exopolymer particles (TEP) on sinking velocity of Nitzschia closterium aggregates. Mar Ecol Prog Ser 182:69-76

Fortier M, Fortier L, Michel C, Legendre L (2002) Climatic and biological forcing of the vertical flux of biogenic particles under seasonal Arctic sea ice. Mar Ecol Prog Ser 225:1-16

Frankenstein G, Garner R (1967) Equations for determining the brine volume of sea ice from $-0.5^{\circ}$ to $-22.9^{\circ} \mathrm{C}$. J Glaciol 6:943-944

Garrison DL, Buck KR (1986) Organism losses during ice melting: a serious bias in sea ice community studies. Polar Biol 6:237-239

Giannelli V, Thomas DN, Haas C, Kattner G, Kennedy H, Dieckmann GS (2001) Behaviour of dissolved organic matter and inorganic nutrients during experimental seaice formation. Ann Glaciol 33:317-321
Gosselin M, Legendre L, Therriault JC, Demers S (1990) Light and nutrient limitation of sea-ice microalgae (Hudson Bay, Canadian Arctic). J Phycol 26:220-232

Gradinger R (1999) Vertical fine structure of the biomass and composition of algal communities in Arctic pack ice. Mar Biol 133:745-754

Gradinger R, Ikävalko J (1998) Organism incorporation into newly forming Arctic sea ice in the Greenland Sea. J Plankton Res 20:871-886

Gradinger R, Nürnberg D (1996) Snow algal communities on Arctic pack ice floes dominated by Chlamydomonas nivalis (Bauer) Wille. Proc Natl Inst Polar Res (NIPR) Symp Polar Biol 9:35-43

Gradinger R, Zhang Q (1997) Vertical distribution of bacteria in Arctic sea ice from the Barents and Laptev Seas. Polar Biol 17:448-454

Gradinger R, Spindler M, Weissenberger J (1992) On the structure and development of Arctic pack ice communities in Fram Strait: a multivariate approach. Polar Biol 12: 727-733

Gradinger R, Friedrich C, Spindler M (1999) Abundance, biomass and composition of the sea ice biota of the Greenland Sea pack ice. Deep-Sea Res Part II Top Stud Oceanogr 46: $1457-1472$

Grasshoff K, Ehrhardt M, Kremling K (1983) Methods of seawater analyses. Verlag Chemie, Weinheim

Grossmann S, Dieckmann GS (1994) Bacterial standing stock, activity, and carbon production during formation and growth of sea ice in the Weddell Sea, Antarctica. Appl Environ Microbiol 60:2746-2753

Herborg LM, Thomas DN, Kennedy H, Haas C, Dieckmann GS (2001) Dissolved carbohydrates in Antarctic sea ice. Antarct Sci 13:119-125

Hoagland KD, Rosowski JR, Gretz MR, Roemer SC (1993) Diatom extracellular polymeric substances. Function, fine structure, chemistry, and physiology. J Phycol 29:537-566

Horner R, Ackley SF, Dieckmann GS, Gulliksen B and 6 others (1992) Ecology of sea ice biota. 1. Habitat, terminology, and methodology. Polar Biol 12:417-427

Junge K, Krembs C, Deming J, Stierle A, Eicken H (2001) A microscopic approach to investigate bacteria under in situ conditions in sea ice samples. Ann Glaciol 33:304-310

Krembs C, Engel A (2001) Abundance and variability of microorganisms and transparent exopolymer particles across the ice-water interface of melting first-year sea ice in the Laptev Sea (Arctic). Mar Biol 138:173-185

Krembs C, Gradinger R, Spindler M (2000) Implications of brine channel geometry and surface area for the interaction of sympagic organisms in Arctic sea ice. J Exp Mar Biol Ecol 243:55-80

Krembs C, Mock T, Gradinger R (2001) A mesocosm study of physical-biological interactions in artificial sea ice: effects of brine channel surface evolution and brine movement on algal biomass. Polar Biol 24:356-364

Leppäranta M, Manninen T (1988) The brine and gas content of sea ice with attention to low salinities and high temperatures. Finn Inst Mar Res Int Rep 2:1-14

Leppard GG (1995) The characterization of algal and microbial mucilages and their aggregates in aquatic ecosystems. Sci Total Environ 165:103-131

Liu H, Buskey EJ (2000) Hypersalinity enhances the production of extracellular polymeric substance (EPS) in the Texas brown tide alga, Aureoumbra lagunensis (Pelagophyceae). J Phycol 36:71-77

Mari X (1999) Carbon content and C:N ratio of transparent exopolymeric particles (TEP) produced by bubbling exudates of diatoms. Mar Ecol Prog Ser 183:59-71 
Mari X, Burd A (1998) Seasonal size spectra of transparent exopolymeric particles (TEP) in a coastal sea and comparison with those predicted using coagulation theory. Mar Ecol Prog Ser 163:63-76

Mari X, Kiørboe T (1996) Abundance, size distribution and bacterial colonization of transparent exopolymeric particles (TEP) during spring in the Kattegat. J Plankton Res 18:969-986

Maykut GA (1985) The ice environment. In: Horner RA (ed) Sea ice biota. CRC Press, Boca Raton, FL, p 21-82

McCave IN (1984) Size spectra and aggregation of suspended particles in the deep ocean. Deep-Sea Res 31:329-352

McConville MJ (1985) Chemical composition and biogeochemistry of sea ice microalgae. In: Horner RA (ed) Sea ice biota. CRC Press, Boca Raton, FL, p 105-129

Mock T, Gradinger R (1999) Determination of Arctic ice algal production with a new in situ incubation technique. Mar Ecol Prog Ser 177:15-26

Mopper K, Zhou J, Ramana KS, Passow U, Dam HG, Drapeau DT (1995) The role of surface-active carbohydrates in the flocculation of a diatom bloom in a mesocosm. Deep-Sea Res Part II Top Stud Oceanogr 42:47-73

Myklestad SM (1995) Release of extracellular products by phytoplankton with special emphasis on polysaccharides. Sci Total Environ 165:155-164

Passow U (2000) Formation of transparent exopolymer particles, TEP, from dissolved precursor material. Mar Ecol Prog Ser 192:1-11

Passow U (2002) Production of transparent exopolymer particles (TEP) by phyto- and bacterioplankton. Mar Ecol Prog Ser 236:1-12

Passow U, Alldredge AL (1994) Distribution, size and bacterial colonization of transparent exopolymer particles (TEP) in the ocean. Mar Ecol Prog Ser 113:185-198

Passow U, Alldredge AL, Logan BE (1994) The role of particulate carbohydrate exudates in the flocculation of diatom blooms. Deep-Sea Res Part I Oceanogr Res Pap 41: 335-337

Passow U, Shipe RF, Murray A, Pak DK, Brzezinski MA, Alldredge AL (2001) The origin of transparent exopolymer particles (TEP) and their role in sedimentation of particulate matter. Cont Shelf Res 21:327-346

Penny DM, Sullivan CW (1990) Bacterial distribution and activity in Weddell-Scotia Sea pack ice during austral winter. EOS Trans Am Geophys Union 71:79

Porter KG, Feig YS (1980) The use of DAPI for identifying and counting aquatic microflora. Limnol Oceanogr 25: 943-948

Raymond JA, Sullivan CW, DeVries AL (1994) Release of an ice-active substance by Antarctic sea ice diatoms. Polar Biol 14:71-75

Riebesell U, Schloss I, Smetacek V (1991) Aggregation of algae released from melting sea ice: implications for seeding and sedimentation. Polar Biol 11:239-248

Sachs L (1984) Angewandte Statistik. Springer-Verlag, Berlin

Schauer U (2000) The expedition ARKTIS XV/3 of the Research Vessel 'Polarstern' in 1999. Rep Polar Res 350: $1-63$

Schuster S, Herndl GJ (1995) Formation and significance of transparent exopolymer particles in the northern Adriatic Sea. Mar Ecol Prog Ser 124:227-236

Shen HT, Ackermann NL (1990) Wave-induced sediment enrichment in coastal ice cover. In: Ackley SF, Weeks WF

Editorial responsibility: Otto Kinne (Editor),

Oldendorf/Luhe, Germany (eds) Sea ice properties and processes, CRREL Monogr 901, US Army Corps of Engineers, Hanover, NH, p 100-102

Simon M, Grossart HP, Schweitzer B, Ploug H (2002) Microbial ecology of organic aggregates in aquatic ecosystems. Aquat Microb Ecol 28:175-211

Smith DC, Simon M, Alldredge AL, Azam F (1992) Intense hydrolytic activity on marine aggregates and implications for rapid particle dissolution. Nature 359:139-142

Smith DJ, Underwood GJC (1998) Exopolymer production by intertidal epipelic diatoms. Limnol Oceanogr 43:1578-1591

Smith DJ, Underwood GJC (2000) The production of extracellular carbohydrates by estuarine benthic diatoms: the effects of growth phase and light and dark treatment. J Phycol 36:321-333

Smith REH, Harrison WG, Harris LR, Herman AW (1990) Vertical fine structure of particulate matter and nutrients in sea ice of the High Arctic. Can J Fish Aquat Sci 47: $1348-1355$

Smith WO Jr, Sakshaug E (1990) Polar phytoplankton. In: Smith WO Jr (ed) Polar oceanography. Part B. Chemistry, biology and geology. Academic Press, San Diego, p $447-525$

Sommer U (1998) Biologische Meereskunde. Springer-Verlag, Berlin

Spindler M (1994) Notes on the biology of sea ice in the Arctic and Antarctic. Polar Biol 14:319-324

Spindler M, Dieckmann GS (1986) Distribution and abundance of the planktic foraminifer Neogloboquadrina pachyderma in sea ice of the Weddell Sea (Antarctica). Polar Biol 5:185-191

Staats N, Stal LJ, Mur LR (2000) Exopolysaccharide production by the epipelic diatom Cylindrotheca closterium: effects of nutrient conditions. J Exp Mar Biol Ecol 249: $13-27$

Stoderegger KE, Herndl GJ (1999) Production of exopolymer particles by marine bacterioplankton under contrasting turbulence conditions. Mar Ecol Prog Ser 189:9-16

Thomas DN, Dieckmann GS (2002) Antarctic sea ice-a habitat for extremophiles. Science 295:641-644

Thomas DN, Lara RJ, Eicken H, Kattner G, Skoog A (1995) Dissolved organic matter in Arctic multi-year sea ice during winter: major components and relationship to ice characteristics. Polar Biol 15:477-483

Thomas DN, Kattner G, Engbrodt R, Giannelli V, Kennedy H, Haas C, Dieckmann GS (2001) Dissolved organic matter in Antarctic sea ice. Ann Glaciol 33:297-303

Utermöhl H (1958) Zur Vervollkommnung der quantitativen Phytoplankton-Methodik. Mitt Int Ver Theor Angew Limnol 9:1-38

Verardo DJ, Froelich PN, McIntyre A (1990) Determination of organic carbon and nitrogen in marine sediments using the Carlo Erba Na-1500 analyzer. Deep-Sea Res Part I Oceanogr Res Pap 37:157-167

Weeks WF, Ackley SF (1986) Chapter 1: The growth, structure, and properties of sea ice. In: Untersteiner $\mathrm{N}(\mathrm{ed}) \mathrm{The}$ geophysics of sea ice. Plenum Press, New York, p 9-164

Wetherbee R, Lind JL, Burke J, Quatrano RS (1998) The first kiss: establishment and control of initial adhesion by raphid diatoms. J Phycol 34:9-15

Zhou J, Mopper K, Passow U (1998) The role of surface-active carbohydrates in the formation of transparent exopolymer particles by bubble adsorption of seawater. Limnol Oceanogr 43:1860-1871

Submitted: June 5, 2002; Accepted: November 14, 2002

Proofs received from author(s): February 3, 2003 